\title{
PARTICIPATION OF THE KALMYKS AS A PART OF THE DON COSSACK MILITARY DIVISIONS IN THE RUSSO-JAPANESE WAR OF 1904-1905
}

\author{
Konstantin N. Maksimov \\ Kalmyk Institute for Humanities of Russian Academy of Sciences, Elista, Russian Federation
}

\begin{abstract}
The article considers the involvement of the Don Cossacks, including Kalmyks as a part of the Don Cossack regiments, in the Russo-Japanese war of 1904-1905 provoked by Japan. Four regiments of the 4th Don Cossack privileged division and the 3rd artillery division battled against the Japanese troops in the Far East. There were more than 70 Cossack Kalmyks. The division and an artillery division were included in the Western group on arrival to the Far East, and then after reorganization - in the 2nd Manchurian army. The Don regiments actively joined in large fighting, prospecting operations. They caused a stir especially in fights for the Lidiutun settlement, in the region of Sandepu, etc. Many Cossacks and officers (including Cossack Kalmyks) of four regiments of a division and two artillery batteries have received high military awards - the Orders of Saint George, St. George's Crosses, medals of St. George for the feats shown in fights. However losses were considerable.

Due to the invasion of Japanese into Mongolia and their attack on the back of the Russian troops the commander-in-chief A.N. Kuropatkin allocated significant forces, including the 4th Don Cossack division, for a protection of back communications and fight against the Japanese diversionary groups. On the instructions of command they had to carry the active fight against the Japanese saboteurs on the extensive territory of Mongolia. For courage and skillful actions in these fights many Cossacks received awards. The Don regiments and artillery division came back home to Don only in April 1906.
\end{abstract}

Key words: Russia, Japan, war, Don division, Far East, Cossacks, Kalmyks, awards.

Citation. Maksimov K.N. Participation of the Kalmyks as a part of the Don cossack military divisions in the Russo-Japanese war of 1904-1905. Vestnik Volgogradskogo gosudarstvennogo universiteta. Serija 4, Istorija. Regionovedenie. Mezhdunarodnye otnoshenija [Science Journal of Volgograd State University. History. Area Studies. International Relations], 2017, vol. 22, no. 2, pp. 76-86. (in Russian).

\section{УЧАСТИЕ КАЛМЫКОВ \\ В СОСТАВЕ ДОНСКИХ КАЗАЧЬИХ ВОЕННЫХ ЧАСТЕЙ В РУССКО-ЯПОНСКОЙ ВОЙНЕ 1904-1905 ГОДОВ}

\author{
Константин Николаевич Максимов \\ Калмыцкий институт гуманитарных исследований РАН, г. Элиста, Российская Федерация
}

Аннотация. В статье рассматривается участие донских казаков, в том числе калмыков в составе донских казачьих полков, в Русско-японской войне 1904-1905 гг., спровоцированной Японией. На Дальнем Востоке с японскими войсками сражались четыре полка 4-й Донской казачьей льготной дивизии и 3-й артиллерийский дивизион. В их составе находилось более 70 калмыков-казаков. Дивизия и артдивизион по прибытии на Дальний Восток были включены в Западный отряд, а затем после реорганизации - во 2-ю Маньчжурскую армию. Донские полки принимали активное участие в крупных боевых действиях, разведывательных операциях. Они особенно отличились в боях за населенный пункт Лидиутунь, в районе Сандепу и др. Многие казаки и 
офицеры четырех полков дивизии и двух артиллерийских батарей, включая и калмыков-казаков, за проявленные в боях подвиги были удостоены высоких воинских наград - орденов, Георгиевских крестов, Георгиевских медалей. Однако и потери были значительны.

В связи с вторжением японцев в Монголию и нападением их на тылы русских войск главнокомандующий А.Н. Куропаткин выделил значительные силы, в том числе 4-ю Донскую казачью дивизию, для охраны тыловых коммуникаций и борьбы с японскими диверсионными отрядами. По заданию командования им пришлось вести активную борьбу с японскими диверсантами на обширной территории Монголии. За мужество и умелые действия в этих боях многие казаки удостоились наград. Донские полки и артдивизион вернулись домой на Дон лишь в апреле 1906 года.

Ключевые слова: Россия, Япония, война, донская дивизия, Дальний Восток, казаки, калмыки, награды.

Цитирование. Максимов, К. Н. Участие калмыков в составе донских казачьих военных частей в Русскояпонской войне 1904-1905 годов / К. Н. Максимов // Вестник Волгоградского государственного университета. Серия 4, История. Регионоведение. Международные отношения. - 2017. - Т. 22, № 2. - С. 76-86.

В 40-х гг. XVII в. небольшие группы калмыков, покинув территорию своего ханства в низовьях Волги, расселились на Дону, где они приобрели равностатусное положение с казачеством, типичные формы его социальной, военной организации и административного управления. В соответствии с новым положением существенно трансформировалась социальная структура донского калмыцкого населения, сложилось и утвердилось военное сословие - служилые калмыки-казаки. Они в составе донских казачьих полков несли службу в различных регионах России и за ее пределами.

Со второй половины XVII в. и на протяжении XVIII-XIX вв. калмыки вместе с донскими казаками защищали южные рубежи Российского государства, участвовали во всех войнах России, которые ей пришлось вести, отстаивая свои геополитические интересы и суверенитет. В первой четверти XVIII в. донские полки в составе российской армии принимали участие в крупных баталиях со шведами, ставших судьбоносными для России, а также в многочисленных войнах с Турцией, Персией. На рубеже XVIII-XIX вв. они воевали на стороне антифранцузских коалиций. Приумножили свою боевую славу донские казаки, в том числе и калмыки, участвуя с народами России в Отечественной войне 1812 г. против армии Наполеона и его союзников, заграничных походах 1813-1814 годов. Калмыкам пришлось воевать вместе с донскими казаками в Крымской (1853-1856 гг.) и Русскотурецкой (1877-1878 гг.) войнах.

В начале XX в. России, защищая свои интересы, территорию, пришлось участвовать в малых и крупных войнах - в Русско-японской (1904-1905 гг.), Первой мировой (19141918 гг.), последствия которых имели глобальное геополитическое значение. В начале века Япония, движимая захватническими замыслами на Дальнем Востоке, в частности притязаниями на Корею и Китай, спровоцировала Россию на войну. В ней калмыки-казаки сражались против японцев в составе донских казачьих полков 4-й Донской казачьей льготной дивизии и 3-го артиллерийского дивизиона.

Статья написана на основе различных исторических источников по происхождению и содержанию. Ее источниковую базу составляют документы фондов № 46 (Атаманская канцелярия) и № 353 (Областной войска Донского статистический комитет) Государственного архива Ростовской области, а также фонда № 2007 (Штаб Верховного главнокомандования. Канцелярия походного атамана при Его императорском величестве) Российского государственного военно-исторического архива, мемуарная литература отечественных авторов, являвшихся участниками боевых действий в Русско-японской войне. Использованы источники, опубликованные в документальных сборниках.

Методологической основной исследования послужил метод познания, опирающийся на принципах историзма, объективности, всестороннего исследования. При изучении и использовании исторических источников применялись методы источниковедческого и компаративного анализа.

По истории этой войны имеется достаточно литературы. В ее историографии выделяются работы Г.Л. Воскобойникова «Каза- 
чество в Русско-японской войне 1904-1905 гг.» (Ростов-на-Дону, 1995), Н.В. Рыжковой «Донское казачество в войнах начала XX века» (М., 2008) и др. Однако в них, как и в других трудах, абсолютно нет никаких сведений об участии калмыков в этой войне. Лишь в книге старшего адъютанта штаба 4-й Донской казачьей льготной дивизии Ф. Ростовцева «4-я Донская казачья дивизия в Русско-японскую войну» (Киев, 1910) показаны отдельные эпизоды боевых действий с участием калмыковказаков.

В конце XIX - в начале XX в. обострившиеся отношения из-за сферы интересов на Дальнем Востоке, в частности - и в Китае, и Корее, как известно, привели к войне Японии с Россией. 26 января 1904 г. Япония, накануне разорвав дипломатические отношения с Россией, без объявления войны напала на ПортАртур (Люйшунь) и нанесла серьезные повреждения двум российским броненосцам и крейсеру, стоявшим на внешнем рейде. На следующий день в неравном бою погибли крейсер «Варяг» и канонерская лодка «Кореец». Началась Русско-японская война, потребовавшая напряжения людских и материальных ресурсов в непростых общественно-политических условиях в стране. Главнокомандующим вооруженными силами на Дальнем Востоке являлся адмирал Е.И. Алексеев, сухопутные войска возглавлял генерал от инфантерии, генерал-адъютант А.Н. Куропаткин, Тихоокеанскую эскадру - вице-адмирал С.О. Макаров.

Первыми в войну вступили части и соединения из Забайкальского, Амурского, Уссурийского, Сибирского, Уральского и Оренбургского казачьих войск. 22 июня 1904 г. высочайшим указом императора Николая II принимается решение направить на Дальневосточный театр военных действий 4-ю Казачью льготную дивизию области войска Донского. Ей был придан 3-й Донской казачий артиллерийский дивизион, который ранее дислоцировался на Украине, в районе Чугуева. Войсковой штаб войска Донского в соответствии с распоряжением правительства России, принятым 25 июня, в тот же день своим приказом объявил 20 июля 1904 г. первым днем мобилизации 4-й Донской казачьей льготной дивизии.

В это время в Донском казачьем войске числились 1876 генералов, штаб- и обер-офи- церов, 170666 нижних чинов, в том числе 3680 калмыков-казаков, а также 48228 верховых лошадей. В 1904 г. калмыцкое население в области войска Донского составляло 31889 человек (16 351 мужчина, 15538 женщин), из них в калмыцких станицах Сальского округа проживали 31187 человек [4, л. 307-308, 337].

4-я Донская казачья дивизия (командующий - генерал-майор М.Н. Телешов, начальник штаба - полковник Н.Г. Филимонов) формировалась в составе 4 донских казачьих полков и для удобства управления делилась на две бригады. В 1-ю бригаду (командир - генерал-майор М.П. Стоянов) входили 19-й (командир - войсковой старшина П.Г. Пахомов) и 24-й (командир - войсковой старшина В.В. Попов) донские казачьи полки, во 2-ю бригаду (командир - генерал-майор Ф.Ф. Абрамов) - 25-й (командир - полковник В.И. Медведев) и 26-й (командир - войсковой старшина М.В. Багаев) донские казачьи полки. 3-м Донским артиллерийским дивизионом, состоявшим из 2-й Донской казачьей батареи (командир - войсковой старшина С.И. Тарашкин) и 3-й Донской казачьей батареи (командир полковник Н.А. Евсегнеев), командовал полковник Н.М. Кузнецов.

Полки 4-й Донской казачьей дивизии комплектовались казаками из разных станиц области. Личный состав 19-го Донского казачьего полка формировался из казаков НижнеКурмоярской, Баклановской, Кутейниковской, Иловайской, Филипповской, Терновской, Цимлянской, Чертковской станиц; 24-го Донского казачьего полка - из станиц Новочеркасской, Кривянской, Грушевской, Аксайской, Александровской, Гниловской, Ольгинской, Хомутовской, Кагальницкой, Мечетинской, Владимирской; 25-го Донского казачьего полка - из Раздорской, Кочетовской, Золотовской, Великокняжеской, Семикаракорской, Нижне-Кундрюческой, Верхне-Кундрюческой, Константиновской, Екатерининской, Усть-Быстрянской станиц; 26-го Донского казачьего полка - из Богоявленской, Николаевской, Мариинской, Камышевской, Семикаракорской, Золотовской, Константиновской, Ермаковской, Денисовской, Платовской и Николаевской станиц.

В состав 2-й и 3-й батарей 3-го Донского артдивизиона входили казаки Гундоровской, Луганской, Каменской, Богоявленской, Мече- 
тинской, Екатерининской, Ермаковской, Митякской, Верхне-Кудрюческой, Еланской, Филипповской, Вешенской, Баклановской, Семикаракорской, Мелеховской, Усть-Быстрянской, Милютинской, Нижне-Кудрюческой, Есауловской, Камышевской, Кобылянской, Пятиизбенской, Золотовской станиц.

По боевому штатному расписанию каждый казачий полк 4-й Донской дивизии имел 25-26 генералов и офицеров, 975-980 нижних чинов, 940-950 верховых лошадей. Основная масса калмыков-казаков (в пределах 70 человек) 4-й Донской дивизии представляла 5 станиц Сальского округа - Баклановскую, Кутейниковскую, Платовскую, Денисовскую, Иловайскую. Призываемые казаки 4-й дивизии, как и все призывники в остальные полки, обязаны были прибыть со своей лошадью. Однако немногие из бедных казаков могли за свой счет приобрести строевую лошадь, обмундирование, снаряжение. В связи с этим выезжавшим на Дальневосточный фронт казакам выделяли из войскового капитала единовременное пособие в сумме ста рублей для приобретения обмундирования и иного военного снаряжения [11, с. 7-8; 14, с. 20]. А казаки, призываемые на строевую службу в другие донские полки, все же должны были приобрести снаряжение за свой счет. Калмыкиказаки должны были полностью снаряжаться за счет станичных сумм, полученных от сдачи в аренду общественных земель. Но это положение не всегда выполнялось. Как вспоминал призывник 1904 г. в 9-й Донской казачий полк, участник Первой мировой войны О.И. Городовиков: «На службу нужно было прийти со своим конем, с седлом, с острой казачьей шашкой, с полной обмундировкой: шинелью, мундиром, шароварами, фуражкой, сапогами, бельем... Мне пришлось заложить свой земельный пай на шесть лет, чтобы купить коня, шашку и снаряжение» $[2$, с. $32 ; 6$, c. 1004]. Кстати, в случае необходимости дополнительно должен был быть выставлен на Дальневосточный военный театр и 9-й Донской казачий полк.

16 (29) августа 1904 г. в Персиановском лагере, недалеко от Новочеркасска, где казаки 4-й Донской дивизии проходили подготовку, император Николай II и войсковой наказный атаман генерал-лейтенант К.К. Макси- мович провели смотр ее личного состава и 3-го артдивизиона. На следующий же день началась погрузка полков 4-й Донской казачьей дивизии в железнодорожные составы для отправки на фронт. 30 августа дивизия двинулась в путь, и почти одновременно (4-5 сентября) с ней отправились эшелоны с личным составом и имуществом 3-го Донского артдивизиона на Дальний Восток.

Русская армия на Дальнем Востоке, растянутая на фронте протяженностью 58 км, до 23 ноября 1904 г. делилась на Восточный и Западный отряды. 4-я Донская казачья дивизия, прибывшая в начале октября 1904 г. в Харбин, была включена в состав Западного отряда. Однако в ноябре указанные отряды приказом главнокомандующего всеми сухопутными и морскими вооруженными силами, действующими против Японии, генералом от инфантерии А.Н. Куропаткиным (назначен 13 октября 1904 г.) были расформированы, и на базе их образованы три армии (1-я Маньчжурская, 2-я Маньчжурская и 3-я Маньчжурская).

В соответствии с приказом № 164 от 23 ноября (6 декабря) 1904 г. главнокомандующего А.Н. Куропаткина 4-я Донская казачья дивизия была причислена ко 2-й Маньчжурской армии (командующий - генерал-адъютант О.К. Гриппенберг), в состав которой входили 5-й, 8-й и 10-й Сибирские армейские корпуса, 2-я бригада Оренбургской казачьей дивизии, 1-й Оренбургский, 1-й Аргунский и Амурский казачьи полки, Восточно-Сибирский понтонный батальон [1, с. 52; 12, с. 378].

Вскоре по прибытии донцы активно включились в боевые действия против японцев. 17 октября 1904 г. 19-й, 24-й, 25-й донские полки и 3-й Донской артдивизион провели разведку боем за населенные пункты Фуцзячжуаньцзы и Лидиутунь. Если первая деревня донцами была взята без особых трудностей, то атака за Лидиутунь оказалась неудачной. В бою за нее погибли 15 казаков 19-го Донского казачьего полка, в том числе калмыки-казаки Кутейниковской станицы Авга Шарапов, Кирсан Адьянов, Микуль Уланов, 32 казака получили ранения, в том числе калмыки-казаки из той же станицы Иван Дажнов, Санжа Баранов, приказные Бембя Жиров, Менько Цеденов, Церен Джамбинов. Приказный Цебек Джамбинов из станицы Иловайской, будучи раненым, оставался в строю, 


\section{ОТЕЧЕСТВЕННАЯ ИСТОРИЯ}

за подвиг в этом бою в числе прочих 40 казаков он удостоился знака отличия Военного ордена (Георгиевского креста) 4-й степени (№ 2 858) [11, c. 461, 470-471].

В ноябре 1904 г. донские казаки несли сторожевое охранение, вели активную разведку. Один из таких эпизодов из боевой жизни казаков описал Ф. Ростовцев, служивший старшим адъютантом штаба 4-й Донской казачьей дивизии. В ночь 9 ноября к расположению японцев у деревни Фуцзячжуаньцзы из 19-го и 25-го полков отправили группу разведчиков, включавшую по 16 человек из каждого полка. В группу 19-го полка сотника Краснянского входил калмык-казак Бембет Иванов (Иловайской станицы) из 6-й сотни.

После удачной в ночь с 15 на 16 декабря 1904 г. очередной разведки сотник Краснянский особо отмечал «спокойное, смелое поведение казака Иванова Бембета», который вскоре был произведен в урядники и награжден за многие подвиги знаком отличия Военного ордена 4-й степени (№ 184 365) [5, с. 70; 11, с. 115]. Вместе с ним в 4-й и 5-й сотне этого же полка служили калмыки-казаки Маманжинов, Манжиков и Б. Наминов.

С целью задержки переброски японских войск по железной дороге и выдвижения их к Мукдену в конце декабря 1904 г. штаб 2-й Маньчжурской армии решил направить конный отряд для действий по тылам противника, разгрома главной железнодорожной станции Инкоу. В предписании № 60 от 23 декабря 1904 г. (5 января 1905 г.) начальника штаба 2-й Маньчжурской армии Н.В. Рузского указывалось генерал-лейтенанту П.И. Мищенко, начальнику отдельной Забайкальской казачьей бригады, что под его командованием формируется конный отряд для производства набега на тылы 2-й и 4-й японских армий. В его состав включалась 4-я Донская казачья дивизия, командиру которой предстояло возглавить одну из трех колонн отряда. Группа, в состав которой входил 19-й Донской казачий полк, 28 декабря разгромила до двух рот японцев и заняла г. Ньючжуань. Однако бой главными силами отряда 30 декабря 1904 г. за станцию Инкоу оказался не совсем удачным, вывести ее полностью из строя не получилось. При ее штурме погибли 4 офицера и 57 казаков и драгун, получили ранения 20 офицеров и 171 нижний чин, без вести пропали более 20 казаков. Как предполагал П.Н. Краснов, по всей вероятности, они погибли. По другим данным, то есть в сообщении от 9 (22 января) 1905 г. главнокомандующего всеми сухопутными и морскими вооруженными силами, действующими против Японии, генерала от инфантерии А.Н. Куропаткина императору Николаю II указывалось, что в ходе набега отряда П.И. Мищенко погибли 7 офицеров и

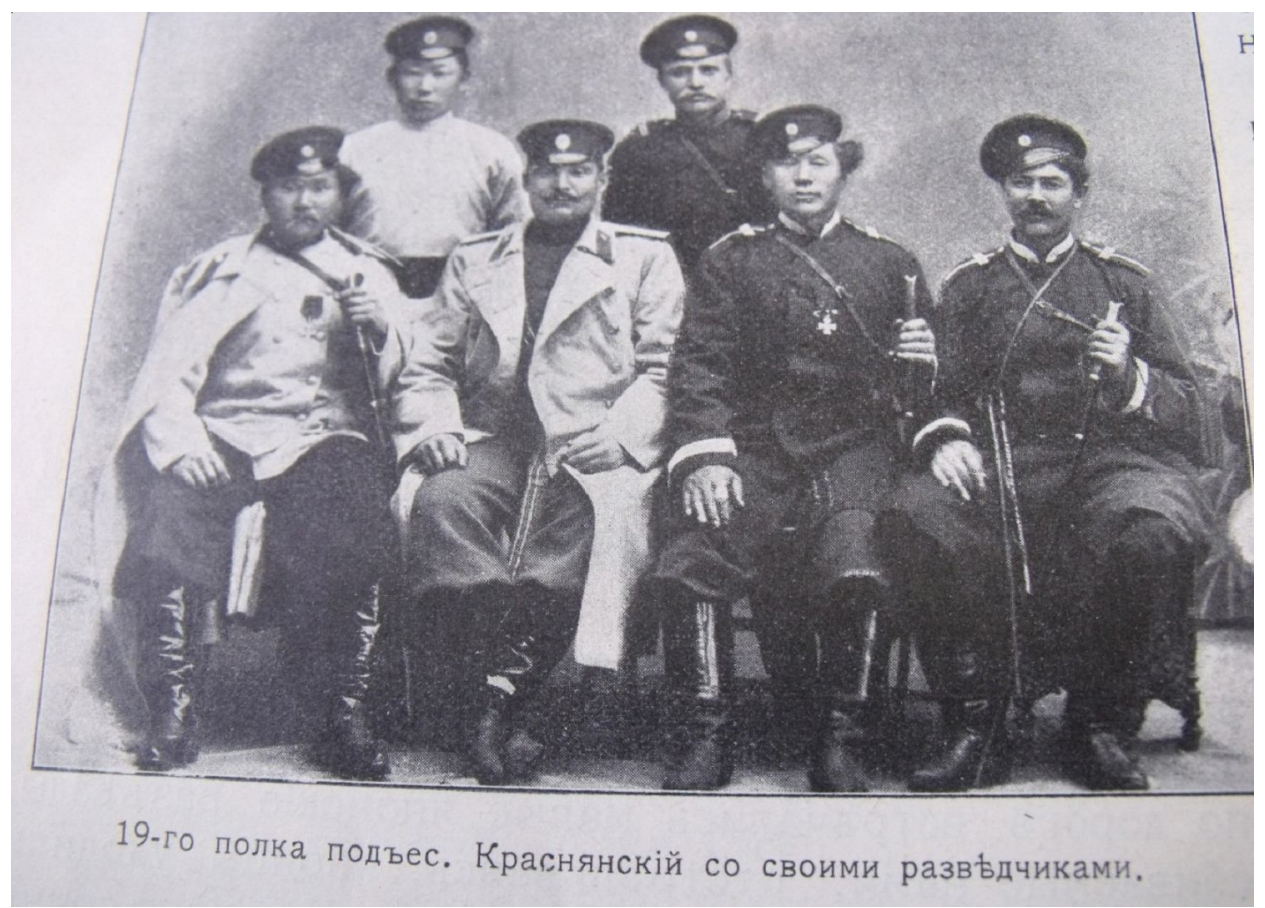


73 нижних чина, ранены 32 офицера и 237 нижних чинов, без вести пропал 21 нижний чин, убито 69 и ранено 75 лошадей $[8$, с. $414 ; 12$, c. $362,370,374]$.

2-й Маньчжурской армии, в составе которой находилась 4-я Донская казачья дивизия, на январь 1905 г. ставилась задача прорвать оборону противника на участке Сандепу - Халентай, овладеть рубежами Цунлянтунь, Тадусанпу, продолжить наступление в направлении д. Шилихэ. 12 января 1905 г. русская конница двумя колоннами под командованием генерала П.И. Мищенко выступила в район Сандепу. Правая колонна (командир - генерал М.Н. Телешов) состояла из 25-го и 26-го донских полков, Кавказской конной бригады, 3-й Донской артбатареи и 20-й конной артбатареи. Левой колонной, составленной из забайкальских и уральских казаков, командовал генерал Павлов. 13 января отряд Мищенко (с 14 января вместо раненого Мищенко отрядом командовал М.Н. Телешов) переправился через реку Хуньхэ и повел наступление во фланг и тыл японцев. Правая его колонна провела удачное наступление и заняла д. Саньтянцзы, выбила японцев из д. Локонго и Нюге и преследовала их до д. Сюерпу. Донцы 25-го и 26-го полков, 3-й Донской артбатареи, захватив д. Уцзягонзу, содействовали наступлению пехоты 1-го Сибирского корпуса на д. Ланцгоу. В бою за д. УЦзягонзу сотня Ф.К. Миронова 26-го полка захватила японский обоз с продовольствием, пленных, прервала телефонную связь противника.

Затем 19-й и 24-й донские полки провели успешные боевые действия за д. Мамакай и Цзяньцзявопу. За эти удачные сражения отряду генерала П.И. Мищенко (М.Н. Телешова) командующий 2-й Маньчжурской армией генераладъютант О.К. Гриппенберг выразил благодарность и пожаловал по 5 знаков отличия Военного ордена на каждую сотню, участвовавшую в атаке японских укрепленных пунктов.

За подвиги в боях в районе Сандепу 65 донских казаков были награждены знаками отличия Военного ордена. В числе получивших награды особо был отмечен и награжден знаком отличия Военного ордена 3-й степени (№ 755) калмык-казак 26-го полка Бадьма Шаргинов (Платовская станица), зарубивший трех японских драгун и захвативший несколько повозок из обоза.
Знаков отличия Военного ордена 4-й степени (Георгиевского креста) также удостоились калмыки-казаки 26-го Донского полка с формулировкой «за мужество и храбрость, оказанные в январских боях 1905 года с японцами»: урядник Андрей Бадьмин (№ 159 481) из Денисовской станицы, приказный Саран Пацынов (№ 159 457) из Платовской станицы, приказный Басан Амарханов (№ 159 490) из Платовской станицы, калмыкказак Соломка Сухаринов (№ 159 459) из Денисовской станицы.

В четырехдневных боях за Сандепу и в его окрестностях русская армия, по данным Генштаба, потеряла 384 офицера и 11364 солдата, японская армия - 8901 человека. В числе раненых из донских казачьих полков в этих боях значились калмыки-казаки Басан Амарханов, Саран Пацынов, Учур Никитин из Денисовской станицы $[7$, с. 653,$660 ; 13$, с. 81,98 , 101, 104].

«Наконец, по донесениям Чичагова, японцы вторглись в Монголию, - писал в своих мемуарах А. Н. Куропаткин, - и при помощи многочисленных шаек хунхузов начали нападать на железную дорогу в тылу нашего расположения. Мне пришлось ослабить нашу армию выделением бригады пехоты и четыре казачьих полков, для усиления охраны дороги нашего тыла» [9, с. 342].

После краткого отдыха 4-я Донская казачья дивизия в соответствии с приказом главнокомандующего А.Н. Куропаткина от 4 февраля 1905 г. приступила к охране тыловых коммуникаций и борьбе с японскими диверсионными отрядами, действовавшими в тылу русской армии. На тот момент боевой состав полков 4-й Донской казачьей дивизии представлялся в следующем виде (см. табл. 1) [1, c. 96-97].

Казакам полков 4-й Донской казачьей дивизии пришлось нести охранно-патрульную службу на обширной территории Монголии, часто вступая в боевые столкновения с японскими диверсионными отрядами. За мужество и умелые действия в боях и в разведке знаками отличия Военного ордена 4-й степени (Георгиевского креста) были отмечены урядник 19-го полка калмык Намга Авюсов (№ 152 618) из Кутейниковской станицы, калмык-казак этого же полка Эрдне Чапинов 
Личный и конский состав полков

\begin{tabular}{|c|c|c|c|c|}
\hline Полки & $\begin{array}{c}\text { Генералы } \\
\text { и офицеры }\end{array}$ & Чиновники & $\begin{array}{c}\text { Нижние } \\
\text { чины }\end{array}$ & Лошади \\
\hline 19-й & 25 & 3 & 901 & 1211 \\
\hline 24-й & 25 & 2 & 795 & 1075 \\
\hline 25-й & 23 & 9 & 534 & 1184 \\
\hline 26-й & 29 & 2 & 817 & 956 \\
\hline Всего в дивизии & 102 & 16 & 3047 & 4426 \\
\hline
\end{tabular}

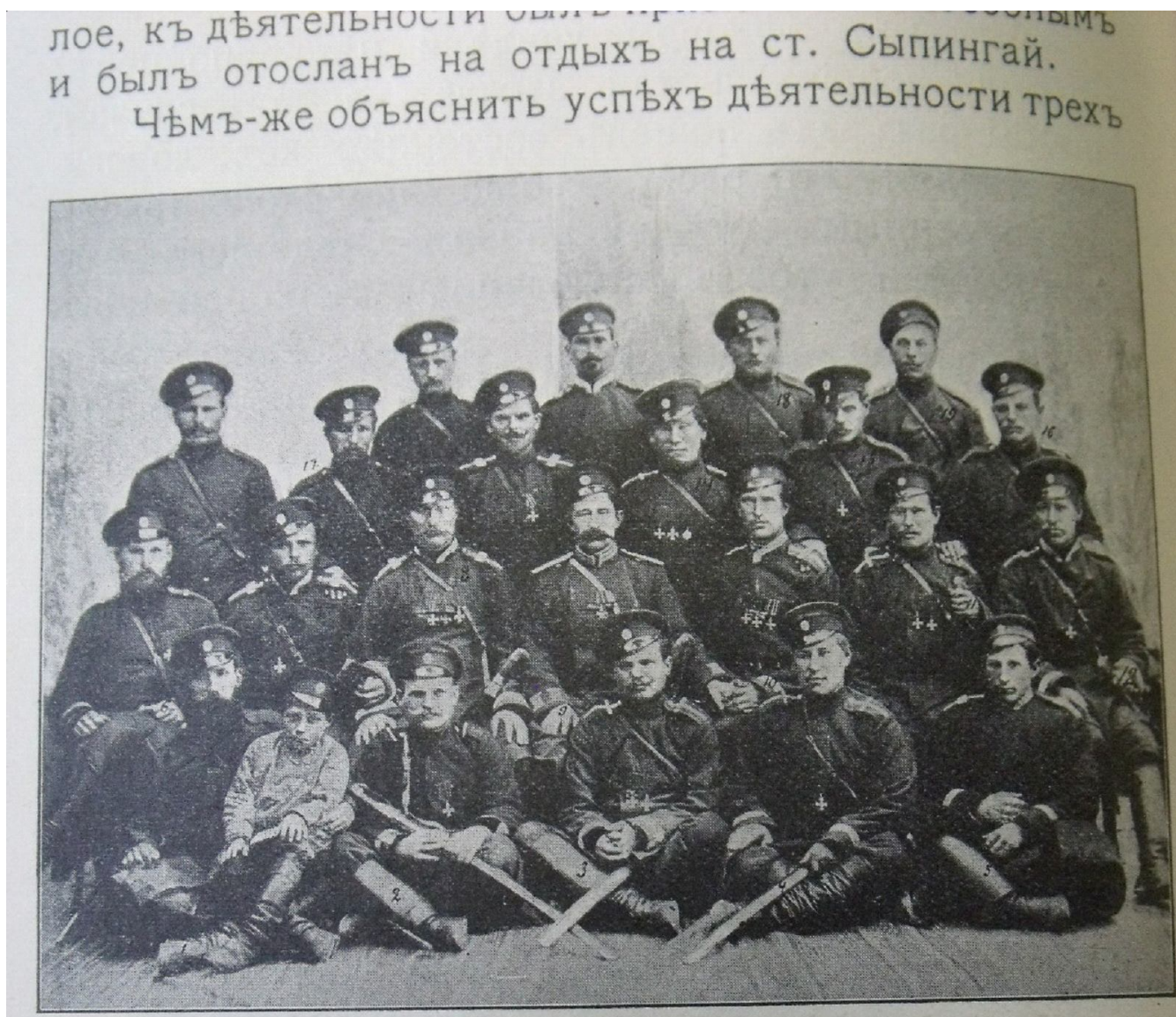

Группа развъдчиковъ 26-го полка подъес. Миронова:

1) Иванъ Гурьевъ съ сыномъ; 2) прик. Өедоръ Кузьменковъ; 3) прик. Арсеній Сизякинъ (раненъ 8 мая); 4) прик. Өедоръ Петровъ; 5) ур. Дмитрій Дмитриченко (раненъ тяжело 8 мая); 6) прик. Иванъ Шеповаловъ; 7) ур. Андрей Өедор. Крикуновъ, замъститель нач. разъъзда; 8) ур. Авакумъ Терентьевичъ Землинъ, доброволецъ, имъетъ всъ 4-ре степени Георгія, легко раненъ у стан. Инкоу; 9) Подъес. Мироновъ; 10) ур. Андрей Өедоровичъ Симоновъ (раненъ тяжело въ руку и грудь 8 мая); 11) прик. Гавріилъ Караичевъ; 12) уряд. Лавренъ Цирульниковъ; 13) вахм. Василій Петровичъ Паршинъ; 14) прик. Бадьма Шаргиновъ, безстрашный герой; 15) каз. Василій Ларіоновъ, доброволецъ; 16) каз. Иванъ Денисовъ; 17) каз. Григорій Хохлачевъ. 
(№ 3 399) из Баклановской станицы, калмыки-казаки 26-го полка Батыр Манунинов (№ 11 444) из Денисовской станицы, Эрдне Чунков (№ 100469 ) из той же станицы. Кроме них, с формулировкой «За личные подвиги, мужество и храбрость, оказанные разновременно в боях с японцами», были награждены Георгиевскими крестами 4-й степени калмыки-казаки 26-го полка Бадьма Шаргинов (№ 183 364), имевший Георгиевский крест 3 -й степени, а также Батыр Харкубенов (№ 124 040) из Денисовской станицы, Эрдне Кумонов (№ 3 898) из той же станицы, 19-го полка - Санжа Баранов (№ 184 377) и Иван Даржинов (№ 121966) из Иловайской станицы, приказный Бадьма Шалхаков (№ 159 950) из той же станицы. Вскоре Бадьма Шаргинов, имевший Георгиевские кресты 4-й и 3-й степени, за подвиг был удостоен Георгиевской медали 4-й степени [11, с. 459-468].

4-я Донская казачья дивизия несла службу не только до прекращения военных действий на всех фронтах, но и вплоть до выезда в марте 1906 г. на Дон. Полки дивизии, 3-й Донской артдивизион, несмотря на то что 31 августа 1905 г. Россия и Япония заключили перемирие и ратифицировали мирный договор 2 октября 1905 года, вернулись домой лишь в апреле 1906 года.

За время боевых действий на Дальнем Востоке 4-я Донская казачья дивизия понесла заметные потери (табл. 2) [11, с. 18].

В числе 57 убитых были 3 калмыка-казака $(5,2 \%$ общего числа погибших казаков дивизии и 4,3 \% общего числа калмыков дивизии), 189 раненых - 10 калмыков-казаков (5,3 \% общего числа раненых казаков и 14,3 \% общего числа калмыков дивизии).

Накануне юбилейных событий династии Романовых общественные организации страны и регионов начали кампанию по увекове- чению памяти погибших в войнах, в том числе и в Русско-японской. В августе 1912 г. Сальский местный отдел «Общества повсеместной помощи пострадавшим на войне солдатам и их семьям» внес в «Комиссию по увековечению памяти воинских чинов, погибших в войну с Японией» (почетный председатель великий князь Михаил Александрович) предложение об установлении на буддийских храмах (хурулах) поминальной доски для увековечения памяти воинских чинов - калмыков буддийского вероисповедания. Эта идея была поддержана названной Комиссией, Центральным правлением «Общества повсеместной помощи пострадавшим на войне солдатам и их семьям» и Департаментом духовных дел Министерства внутренних дел.

Эскиз поминальной доски по увековечению памяти погибших калмыков-казаков в войне с Японией был подготовлен в декабре 1912 г. и одобрен бакшой-ламой донских калмыков М.Б. Барманжиновым и наказным атаманом области Войска Донского, утвержден Комиссией и Департаментом духовных дел МВД. На поминальной доске была сделана на калмыцком языке надпись «За Веру, Царя и Отечества» и на русском языке составлен список (фамилии, имена и отчества с указанием станицы) погибших и умерших от полученных ран в войне с Японией. Поминальные доски были установлены на зданиях хурулов в станицах Денисовской, Платовской, Иловайской, Кутейниковской [3, л. 1-5]. К сожалению, эскизы поминальных досок и нанесенные на них тексты в архивах не сохранились.

В Русско-японской войне донские казаки заметно отличились своим мужеством, дисциплинированностью, боевой подготовкой, умением воевать. По праву многие казаки и офицеры 4-й Донской казачьей дивизии заслужили военные награды. Общее число на-

Потери личного состава полков

\begin{tabular}{|l|r|r|c|c|c|}
\hline Полки & Убито & Ранено & $\begin{array}{l}\text { Пропало } \\
\text { без вести }\end{array}$ & Всего убыло & $\begin{array}{l}\text { Средний спи- } \\
\text { сочный состав }\end{array}$ \\
\hline 19 -й & $20(2 \%)$ & $63(6,6 \%)$ & 3 & $86(9 \%)$ & 950 \\
\hline $24-и ̆$ & $19(2 \%)$ & $36(3,7 \%)$ & 5 & $60(6,1 \%)$ & 949 \\
\hline $25-и ̆$ & $11(1,2 \%)$ & $32(3,4 \%)$ & 7 & $50(5,2 \%)$ & 956 \\
\hline $26-и ̆$ & $7(1,5 \%)$ & $58(6 \%)$ & 5 & $70(7,4 \%)$ & 937 \\
\hline Всего & $57(1,5 \%)$ & $189(5 \%)$ & 20 & $266(7 \%)$ & 3792 \\
\hline
\end{tabular}




\section{ОТЕЧЕСТВЕННАЯ ИСТОРИЯ}

гражденных донских казаков по полкам представлено в таблице 3 [11, с. 19].

В числе награжденных казаков 4-й Донской дивизии были 17 калмыков-казаков (3\% общего количества получивших награды и 23,2 \% общего числа калмыков дивизии), из них Бадьма Шаргинов удостоился двух Георгиевских крестов (4-й и 3-й степени) и Георгиевской медали, Баклан Янжинов, личный коновод генерала от инфантерии главнокомандующего А.Н. Куропаткина, - Георгиевских крестов 4-й и 3-й степени, Чонкуш Алцадыков из разведгруппы урядника Козадорова 6-й сотни 26-го полка (станица Денисовская) - Георгиевского креста 4-й степени за взятие в разведке в плен двух японцев. Старший адъютант штаба 4-й Донской казачьей дивизии Ф. Ростовцев, характеризуя участие донских казаков в Русско-японской войне по станицам, отмечал: «Весьма храбры были калмыки» $[11$, с. 8].

Эти традиции предков калмыков-казаков продолжили и продемонстрировали в Первую мировую войну дети многих участников Русско-японской войны. К ним можно отнести сыновей, родственников Шаргинова, Шарапова, Иванова, Уланова, Цеденова, А. Мангатова, Джамбинова, Е.А. Басанова, Б. Наминова, Никитина и др., воевавших в составе 5-го генерала Власова, 9-го генерала Орлова-Денисова, 19-го, 39-го и других донских казачьих полков и награжденных знаками военного отличия. А казаку из Денисовской станицы, как и многим другим калмыкам-казакам из калмыцких станиц, Учуру Анчиковичу Мусову, участнику Русско-японской войны, довелось повоевать и в Первую мировую, и в Гражданскую войну [11, л. 3, 4, 6, 111].

Таблица 3

\section{Количество награжденных Георгиевскими крестами по полкам}

\begin{tabular}{|c|c|c|c|c|c|c|}
\hline \multirow[t]{2}{*}{ Полки } & \multirow{2}{*}{$\begin{array}{l}\text { Общее число } \\
\text { награжденных }\end{array}$} & \multicolumn{4}{|c|}{ Из них } & \multirow[t]{2}{*}{ В полку } \\
\hline & & 4-й ст. & 3-й ст. & 2-й ст. & 1-й ст. & \\
\hline 19-й & $176(18 \%)$ & 171 & 12 & 1 & - & 950 \\
\hline 24-й & $121(12,7 \%)$ & 120 & 5 & - & - & 949 \\
\hline 25-й & $103(10,8 \%)$ & 103 & 7 & 1 & - & 956 \\
\hline 26-й & $140(14,9 \%)$ & 140 & 10 & 3 & 1 & 937 \\
\hline Всего & $540(14,3 \%)$ & 534 & 34 & 5 & 1 & 3792 \\
\hline
\end{tabular}

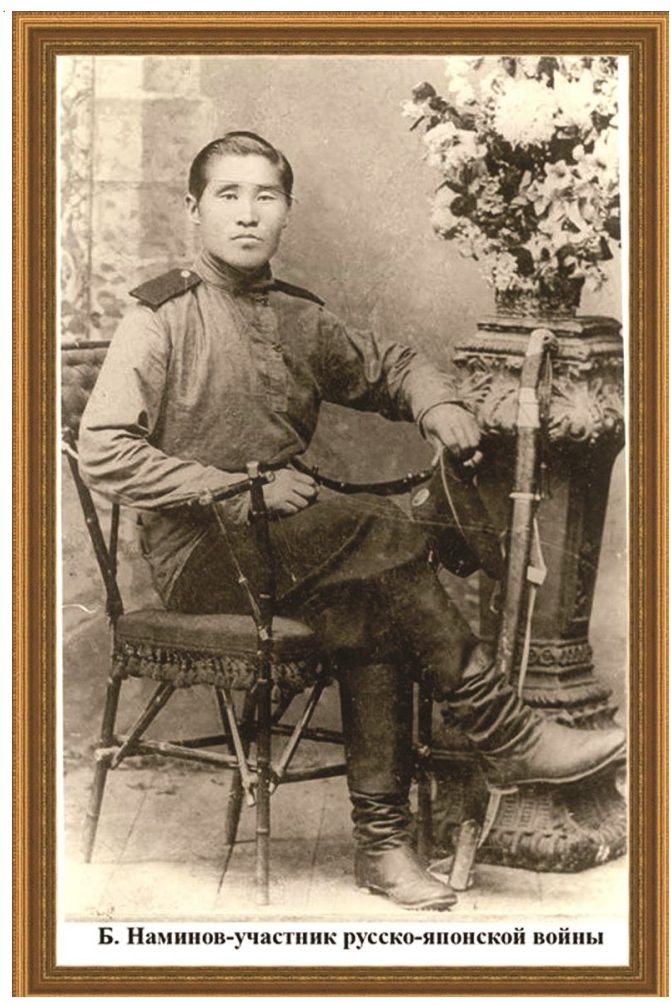


В начале 1906 г. император Николай II учредил памятную медаль трех степеней (серебряную, светло-бронзовую и темно-бронзовую) о войне 1904-1905 годов. Генералы, офицеры и казаки 4-й Донской казачьей дивизии как участники боевых действий в войне с Японией в 1906 г. получили светло-бронзовую медаль для ношения на груди на ленте, составленной из Александровской и Георгиевской. Прибыв на Дон, казаки полков 4-й Донской казачьей дивизии и 3-го Донского артиллерийского дивизиона получили двухмесячный отпуск.

Несмотря на незначительное количество калмыков-казаков, участвовавших в русскояпонской войне в составе четырех донских полков, они продемонстрировали сложившиеся вековые традиции совместной защиты интересов России, общность судьбы, мужество, умение в грозное время сплотиться и отстаивать целостность и безопасность страны. Почти трехлетние революционные события в России, в которые было втянуто и донское казачество в качестве силы в борьбе с антиправительственными выступлениями, в 1907 г. пошли на убыль. Но и в этих социальных и политических брожениях в среде казачества явно наметилась тенденция к переходу в бифуркационное состояние, до открытого проявления которого оставалось немного времени. Под влиянием революционных событий и калмыки-казаки начали втягиваться в бурную общественно-политическую жизнь Дона.

\section{СПИСОК ЛИТЕРАТУРЫ}

1. Воскобойников, Г. Л. Казачество в Русскояпонской войне 1904-1905 гг. / Г. Л. Воскобойников. - Ростов н/Д : Науч. б-ка Рост. н/Д гос. ун-та, 1995. $-110 \mathrm{c}$.

2. Городовиков, О. И. В боях и походах. Воспоминания / О. И. Городовиков. - М. : Дет. лит., 1979. $-206 \mathrm{c}$.

3. Государственный архив Ростовской области (далее- ГА РО). - Ф. 46. - Оп. 1. - Д. 3652.

4. ГА РО. -Ф. 353.- Оп. 1.- Д. 603.

5. Добрынин, В. В. Донцы в Маньчжурии. Путевые, походные и боевые воспоминания и краткая историческая справка 3-й Донской казачьей батареи / В. В. Добрынин. - Новочеркасск : Част. дон. тип., 1907. $-166 \mathrm{c}$. №36.
7. История Русско-японской войны : в 6 т. Т. III / ред.-изд. М. Е. Бархатов, В. В. Функе. - СПб. : Товарищество Р. Голике и А. Вильборгъ, 1907. - 302 с.

8. Краснов, П. Н. История Войска Донского. Картины былого Тихого Дона / П. Н. Краснов. М. : Вече, 2007. $-448 \mathrm{c}$.

9. Куропаткин, А. Н. Записки о Русско-японской войне / А. Н. Куропаткин. - М. : Вече, 2015.$500 \mathrm{c}$.

10. Российский государственный военно-исторический архив. - Ф. 2007. - Оп. 1. - Д. 30.

11. Ростовцев, Ф. 4-я Донская казачья дивизия в Русско-японскую войну / Ф. Ростовцев. - Киев : Тип. т-ва И.Н. Кушнерев и К ${ }^{\circ} 1910 .-485$ с.

12. Русско-японская война 1904-1905 гг. Действия сухопутных войск : сб. док. - М. : Воениздат, $1941 .-528 \mathrm{c}$.

13. Русско-японская война в сообщениях Николаевской академии Генерального штаба : в 2 ч. Ч. 2. - СПб. : Тип. С.Г. Кнорус, 1907. - 326 с.

14. Рыжкова, Н. В. Донское казачество в войнах начала XX века / Н. В. Рыжкова. - М. : Вече, 2008. $-448 \mathrm{c}$.

\section{REFERENCES}

1. Voskoboynikov G.L. Kazachestvo v Russkoyaponskoy voyne 1904-1905 gg. [Cossacks in the Russian-Japanese War in 1904-1905]. Rostov-on-Don, Nauch. b-ka Rost. n/D gos. un-ta, 1995. $110 \mathrm{p}$.

2. Gorodovikov O.I. V boyakh i pokhodakh. Vospominaniya [In Battles and Military Campaigns. Memories]. Moscow, Det. lit. Publ., 1979. 206 p.

3. Gosudarstvennyy arkhiv Rostovskoy oblasti [State Archive of the Rostov Region], F. 46, Op. 1, D. 3652 .

4. Gosudarstvennyy arkhiv Rostovskoy oblasti [State Archive of the Rostov Region], F. 353, Op. 1, D. 603.

5. Dobrynin V.V. Dontsyv Manchzhurii. Putevye, pokhodnye i boevye vospominaniya i kratkaya istoricheskaya spravka 3-y Donskoy kazachey batarei [The Donets in Manchuria. Travel, Campaign and Fighting Memories and a Brief Historical Background of the 3rd Don Cossack Battery]. Novocherkassk, Chast. don. tip., 1907. 166 p.

6. Donskie eparhialnye vedomosti, 1911, no. 36 .

7. Barkhatov M.E., Funke V.V., eds. Istoriya Russko-yaponskoy voyny: $v 6$ t. T. 3 [History of the Russo-Japanese War. In 6 vols. Vol. 3]. Saint Petersburg, Tovarishchestvo R. Golike i A. Vilborg, 1907. 302 p.

8. Krasnov P.N. Istoriya Voyska Donskogo. Kartiny bylogo Tikhogo Dona [History of the Don Army. Pictures of the Former Silent Don]. Moscow, Veche Publ., 2007. 448 p. 


\section{ОТЕЧЕСТВЕННАЯ ИСТОРИЯ}

9. Kuropatkin A.N. Zapiski o Russkoyaponskoy voyne [Notes on the Russo-Japanese War]. Moscow, Veche Publ., 2015. 500 p.

10. Rossiyskiy gosudarstvennyy voennoistoricheskiy arkhiv [Russian State Military and Historical Archive], F. 2007, Op. 1, D. 30.

11. Rostovtsev F. 4-ya Donskaya kazachya diviziya $v$ Russko-yaponskuyu voynu [4th Don Cossack Division in the Russo-Japanese War]. Kiev, tip. t-va I.N. Kushnerev i Ko, 1910.485 p.

12. Russko-yaponskaya voyna 1904-1905 gg. Deystviya sukhoputnykh voysk. Sbornik dokumentov
[The Russo-Japanese War of 1904-1905. Actions of the Land Forces. Collection of Documents]. Moscow, Voenizdat Publ., 1941. 528 p.

13. Russko-yaponskaya voyna $v$ soobshcheniyakh Nikolaevskoy akademii Generalnogo shtaba: $v 2$ ch. Ch. 2 [The Russo-Japanese War in the Reports of the Nikolaev Academy of the General Staff. In 2 Parts. Part 2]. Saint Petersburg, tip. S.G. Knorus, 1907.326 p.

14. Ryzhkova N.V. Donskoe kazachestvo $v$ voynakh nachala $X X$ veka [Don Cossacks in the Wars of the Early 20th Century]. Moscow, Veche Publ., 2008. $448 \mathrm{p}$.

\section{Information about the Author}

Konstantin N. Maksimov, Doctor of Sciences (History), Professor, Chief Researcher, Department of History, Kalmyk Institute for Humanities of Russian Academy of Sciences, I.K. Ilishkina St., 8, 358000 Elista, Russian Federation, maksimovkn@kigiran.com, http://orcid.org/0000-0002-9475-6137.

\section{Информация об авторе}

Константин Николаевич Максимов, доктор исторических наук, профессор, главный научный сотрудник отдела истории, Калмыцкий институт гуманитарных исследований РАН, ул. им. И.К. Илишкина, 8, 358000 г. Элиста, Российская Федерация, maksimovkn@kigiran.com, http://orcid.org/0000-0002-9475-6137. 